

\title{
Low-Pay Mobility in the Swiss Labor Market
}

\section{Augustin de Coulon}

Centre for Economic Performance

London School of Economics and Political Science

Houghton Street, London WC2A 2AE, United Kingdom

Email: a.de-coulon@Ise.ac.uk
Boris A. Zürcher

\author{
State Secretariat for Economic Affairs \\ Bundesgasse 8, CH-3003 Berne, Switzerland \\ Email: boris.zuercher@seco.admin.ch
}

November 2001

\begin{abstract}
:
This paper uses a panel of 7617 individuals drawn from the Swiss Labor Force Survey (SLFS) to study i) low-pay incidence and ii) individual transition probabilities at the lower end of the wage distribution. In a first step, various raw transition probabilities are computed for the period between 1992 and 1998, and some descriptive and comparative statistics on wage mobility are presented. In the second step, the determinants of low-pay incidence are estimated, and in a third step, the determinants of transitions into and out of the low-pay segment are analyzed. This analysis is based on a bivariate probit model which takes into account the potential endogeneity of the initial state.

With regard to low-pay incidence the results to a large extent confirm previous ones obtained by standard wage equations. Low-pay incidence is influenced by certain personal characteristics, but as well by the affiliation to particular economic sectors. When investigating mobility, it is found that low-pay spells are both, transitory and persistent events. On the one hand, many workers low-paid at some point in time succeed to escape the lowpay segment within a two-year period. For those remaining low-paid, on the other hand, our results suggest that state dependence rather than heterogeneity seems to affect more the persistence in low-pay status.
\end{abstract}

Keywords: $\quad$ low-pay, wage mobility, transition models

JEL-classification: J31, D31, C25

* Many thanks to Michel Kolly from the Swiss Federal Statistical Office (SFSO) for advices on the data set. Many thanks to J. Haskel (Queen Mary, University of London), R. Dickens (Queen Mary, University of London and Centre for Economic Performance) for their numerous and helpful comments. We are also grateful to an anonymous referee for important suggestions that have substantially improved this paper. Financial support under grant no: 8210-61262 from the Swiss National Science Foundation is gratefully acknowledged by A. de Coulon. Part of the work was conducted while he visited the Department of Economics, Queen Mary, University of London. The department's hospitality is gratefully acknowledged. 


\section{Introduction}

During the eighties and nineties the Swiss labor market has forfeited much of its former flexibility at the aggregate level. Many factors account for this, but the most important ones certainly are a higher attachment of women to the labor market, an increased share of foreign workers with low skills in the labor force, and legislative changes with regard to eligibility criteria for unemployment benefits. These developments rather specific to the Swiss situation were accompanied by an accelerated structural change common to most industrialized economies, reflected by continuously shrinking employment opportunities in manufacturing, an increasing employment share of the service sector, and an accelerated skill-biased technological progress. The decline in labor market flexibility at the aggregate level, i.e the reduced capacity of aggregate labor demand and supply to rapidly adapt to external shocks, clearly calls for a larger flexibility at the individual level either in terms of wage or labor volume adjustments when the objective of full employment is to be achieved. Considering the Swiss experience, the share of part-time jobs has indeed steadily increased over the past decade, but as well other forms of flexible work arrangements have gained importance. Overall these developments have raised concerns about job quality and inequality in the wage distribution, particularly so for the low-skilled workers. In Switzerland the discussion with regard to job quality was further stimulated by the exceptionally long lasting period of economic stagnation during the nineties which brought about a high level of structural unemployment among the low-skilled. Based on this experience it is argued that a growing proportion of the labor force is either faced with the choice between low-paid work or persistent exclusion from the labor market, and it is generally feared that the Swiss labor market increasingly lacks the capacity to provide sufficient earnings opportunities for a large proportion of the labor force.

Several studies have attempted to document the above mentioned developments in terms of the consequences for wages in Switzerland. Quite surprisingly, a general deterioration of job quality in terms of wages does yet not really show up in the available statistics. It rather looks as if the wage distribution has remained stable in Switzerland over the past decade. ${ }^{1}$ For the period 1991 to 1995 the OECD, for instance, reports an increase in the ratio of the $9^{\text {th }}$ to the $5^{\text {th }}$ decile by 3 percent only and a slight decrease in the ratio of the $5^{\text {th }}$ to the $1^{\text {st }}$ decile by 2 percent for male and female workers. Moreover, investigating low-pay proportions, DEUTSCH et al. (1999) find that the overall share of low-paid workers ("Bas salaires"), defined as those workers whose wage falls short of half the median wage, has remained constant at roughly 19.5 percent between 1991 and $1997 .{ }^{2}$ Considering only full-time workers they even find a slight decrease from 5.1 percent in 1991 to 3.4 percent in 1997.

Considering these evidences it needs, however, to be acknowledged that the statistics cited so far refer to a static concept of the wage distribution. Knowing, for instance, that a certain proportion $p$ of workers is low

\footnotetext{
${ }^{1}$ See OECD 1996, Deutsch et al. 1999, KÜNG and BlanK 2000, and Federal Office OF Statistics 1996.
} 
paid at a certain point in time can be consistent with a whole range of different pictures when viewed in a dynamic context. If, for example, there is no mobility within the wage distribution, i.e when there is no change in the relative position of workers within the wage distribution, then the proportion $p$ of workers is low-paid throughout their working life. By contrast, when there is complete mobility, an individual will spend a certain time $p$ of his working life in the low-pay segment and the remaining time (1-p) in a higher paid job. The figures for Switzerland mentioned by DEUTSCH et al. could, therefore, be consistent with a situation in which only few workers have experienced a low-pay event (low $p$ ), but where low-pay persistence has increased. The key issue is thus whether persons are trapped in a low-pay career or whether they are just temporarily caught in a low-paying job. In order to assess this issue it is necessary to study the movements within the wage distribution. This exercise subsequently provides a complementary view to the computed low-pay proportions. It emphasizes the dynamics of becoming and remaining low-paid; computing simple low-pay proportions, by contrast, places emphasis on the determinants of being in a low-pay state at some point in time and thus rather stresses the static aspect of wage formation.

The objective of this paper is to provide some insights into wage mobility at the lower end of the wage distribution for Switzerland. In particular we are investigating the probabilities of movements into and out of the low-wage segment defined by certain low-pay thresholds. In a first step of the analysis we propose some descriptive and comparative statistics on low-pay incidence and mobility within the wage distribution. We also briefly look at occupational mobility, for it may well be that workers mobility does not primarily manifest itself through wage adjustments, but rather through labor supply adjustments with oscillations between employment and unemployment representing one extreme form of occupational mobility. Then we follow STEWART and SWAFFIELD (1999) and model transitions into and out of the low-pay segment by means of a bivariate endogenous selection model. This econometric modeling is based on a Markovian concept of mobility as defined by HECKMAN and BORJAS (1980). The analysis allows us to compare the difference between the probability of remaining low-paid and remaining high-paid, and we can thus investigate the observed stylized fact that on average initially low-paid workers have a much higher propensity of being lowpaid again the subsequent period than initially high-paid workers. The methodology applied here also enables us to find out whether this difference stems from the intrinsic difference between the observed characteristics of the low-paid and high-paid individuals (heterogeneity) or whether the experience of a low-pay spell makes them different individuals (state dependence). We may thus assess the factors accounting for low-pay persistence. The distinction between individual heterogeneity and state dependence is highly important in view of the different policy options that could be adopted in order to improve wages of the lowpaid workers.

\footnotetext{
${ }^{2}$ This share is calculated based on the entire active population, i.e. including the self-employed, part-time workers etc..
} 
It should be mentioned that the particular form of state dependence studied here pertains to whether being in a certain state raises a persons probability of remaining in that state, and it should therefore not be confused with duration dependence where the probability of remaining in a state directly depends on the time spent in that state. This Markovian approach to study mobility is mainly chosen for the reason that we have no duration data at hand. As will be seen later on, the approach of STEWART and SWAFFIELD also takes into account the potential selection bias arising when treating the initial state as exogenous (HECKMAN 1981). Within our context, endogenizing the initial state is important because the available data cover a relatively short time period, where the initial state still may have a considerable impact on the subsequent states occupied.

The outline of the paper is as follows: Section two presents the data, defines the low-pay thresholds and investigates overall mobility by means of two kinds of transition matrices. In section three the econometric model is presented and section four provides the results, first for the low-pay incidence and then for the transition probabilities into and out of the low-wage segment. Section five derives figures on state dependence and heterogeneity effects, and section six, finally, concludes with a brief summary and some policy considerations.

\section{Data, Descriptive and Comparative Statistics}

The data are drawn from the Swiss Labor Force Survey, providing information about labor market relevant attributes of workers on an annual basis since 1991. Between 16,000 and 18,000 persons are interviewed by telephone every year in one of the three official languages, French, German and Italian. The survey method implies that individuals not possessing a phone and not speaking one of the official languages are not interviewed. Moreover, seasonal, and cross-border workers are not covered by the survey.

To analyze earnings mobility, what is ideally needed are panel data tracing the same individuals during a certain period of time. Even though the Swiss Labor Force Survey (SLFS) is not really a panel, it is nevertheless possible to follow a certain share of persons over a two year period. This allows us to construct three non overlapping sub-panels covering altogether almost the entire decade of the nineties. To be more precise, each of these panels covers two years (the first one spans from 1992 to 1994, the second one from 1994 to 1996, and the third one from 1996 to 1998). After pooling the data, we finally obtain a raw sample consisting of 19,636 individuals, males and females. The data cover persons aged between 15 and 65 years. Table 1 presents some averaged characteristics of a sub-sample consisting of 11,109 wage earners, whose hourly pay lies between CHF 5 and CHF $500^{3}$ and who were interviewed three years in a row. The means are computed for the respective pooled initial years of each sub-panels, i.e. for 1992, 1994 and 1996.

\footnotetext{
${ }^{3}$ This restriction is introduced as hourly wages outside this range seem highly unlikely in the Swiss labor market. It does furthermore not alter the results in a significant way since only approximately 40 individuals had wages below CHF 5 and beyond CHF 500 an hour in each year.
} 
Table 1: Sample Means (Pooled Data 1992, 1994, 1996)

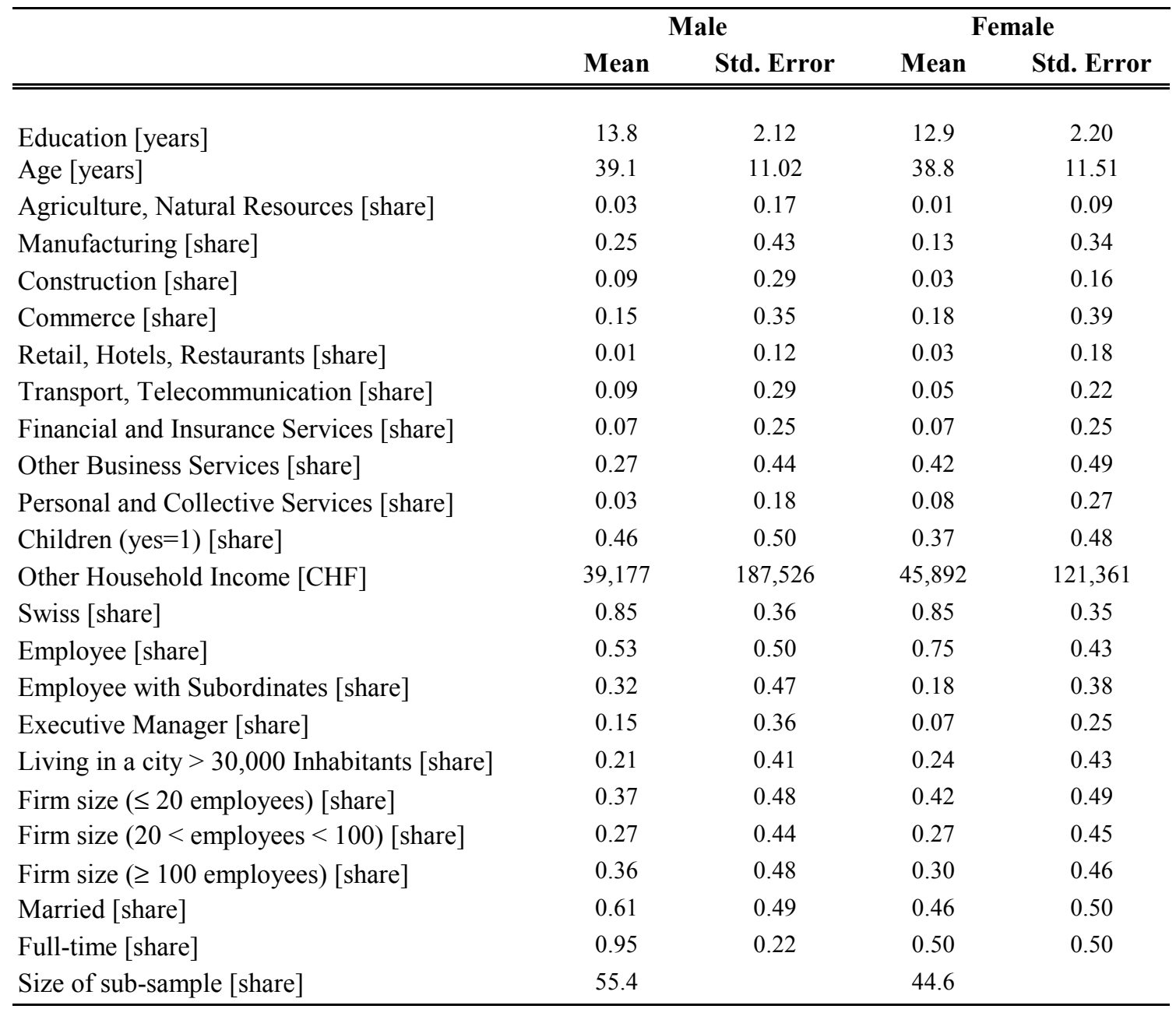

We note that female workers tend to work more often in commerce, retail trade, hotels and restaurants, other business services and personal and collective services than males. The majority of female persons work as employees; very few work as executive managers. Moreover, those women working are for the most part not married, have no children and tend to occupy part-time jobs more often than their male counterparts. Male workers, in turn, are more often in manufacturing, and on the average also work in larger firms. Women are slightly younger in our sample than male workers; we will use this variable as a proxy for labor market experience in the later analysis.

\section{Definition of the Low-Pay Thresholds}

The choice of the low-pay cut-offs clearly depends on the issues being addressed. If the main interest is in the relationship between low-pay and poverty, it may be appropriate to use an absolute measure of low-pay. Relative measures seem more appropriate, in turn, when focusing on low-pay that is not directly related to a subsistence wage level, but rather reflects some kind of decency threshold. In our analysis we have opted for three definitions. First, we adopted two widely used thresholds in order to conduct some comparisons with other studies: the first is half the median gross hourly wage, the second is two third of the median gross 
hourly wage. Secondly, the third threshold is defined as the level of hourly pay corresponding to a monthly nominal gross income of CHF 3,000 in 1998 when working full-time. The choice of this latter threshold is motivated by the recent discussions in Switzerland related to the introduction of a legal minimum wage.

Clearly, the low-pay dynamics may be strongly influenced by the choice of the threshold measures because the wage distribution is usually skewed. The use of proportions such as half or two thirds of the median wage yet assures some robustness. Table 2 summarizes these different thresholds and also displays the corresponding full-time equivalent monthly wage when assuming an average number of 168 normal working hours a month. ${ }^{4}$ The CHF 3,000 threshold has been constructed by calculating a nominal hourly wage with the Nominal Wage Index for 1992, 1994 and 1996. In 1998, this latter threshold amounts to CHF 17.86 an hour.

Table 2: Low-Pay Thresholds; Hourly Wages, Monthly Incomes, and Low Pay Proportions

\begin{tabular}{lcccc}
\hline & $\mathbf{1 9 9 2}$ & $\mathbf{1 9 9 4}$ & $\mathbf{1 9 9 6}$ & $\mathbf{1 9 9 8}$ \\
\hline \hline \multirow{2}{1/2}{ median } & & & & \\
& 14.4 & 14.9 & 14.5 & 14.8 \\
& $(2621)$ & $(2731)$ & $(2642)$ & $(2696)$ \\
CHF 3,000 & $4.7 \%$ & $4.5 \%$ & $4.7 \%$ & $4.4 \%$ \\
& & & & \\
& 16.6 & 17.2 & 17.7 & 17.9 \\
$\mathbf{2 / 3}$ median & $(2776)$ & $(2891)$ & $(2966)$ & $(3000)$ \\
& $8.2 \%$ & $7.8 \%$ & $8.9 \%$ & $9.2 \%$ \\
& 19.2 & 19.9 & & \\
& $(3495)$ & $(3642)$ & $(3523)$ & 19.7 \\
& $15.2 \%$ & $13.5 \%$ & $12.9 \%$ & $13.2 \%$ \\
\hline
\end{tabular}

Note: First line contains hourly wages. The second line contains the monthly wage in brackets, and the last line indicates the low-pay proportion.

We can see that both relative thresholds ( $1 / 2$ and $2 / 3$ of the median) remained quite stable around CHF 14.5 and CHF 19.5 over the sample period. While the wage thresholds display only little variation, it seems interesting to note that the share of persons being paid less than CHF 3,000 a month increased by one percentage point between 1992 and 1998 and the share of persons earning less than 2/3 of the median wage declined by two percentage points during the same period.

\section{Transitions Between Occupational States}

The labor market is in itself a dynamic system where individuals continuously transit between different occupational states. Before starting the analysis of aggregate transitions probabilities between the low- and high-pay segment of the labor market it seems, for this reason, appropriate to investigate these moves be-

\footnotetext{
${ }^{4}$ The difference between the hourly gross and net wage amounts to roughly 15 percent. It also seems worth emphasizing that the interest here lies not on an investigation about the working poor. We have not controlled for whether wages represent the only income or the main income source of a low paid person.
} 
tween different occupational states. Four broad states are distinguished: Employment, apprentice, unemployment and not in the labor force. The employment state is further differentiated into high-paid, low-paid and a state where no wage is reported, but where the person is still included in the sample. We have pooled the data such that the initial period $t-1$ and the final period $t$ consist of all observations in the years $\{1992$, $1994,1996\}$ and $\{1994,1996,1998\}$ respectively. The transitions thus refer to a two-year period.

Table 3: Transitions Between Different Labor Market States of Low- and High-Paid Workers

\begin{tabular}{|c|c|c|c|c|c|c|c|}
\hline \multirow{3}{*}{$\begin{array}{l}\text { Period } \boldsymbol{t} \text {-1 } \\
\text { (State in } 1992 \text { or } 1994 \text { or } 1996)\end{array}$} & & \multicolumn{6}{|c|}{$\begin{array}{c}\text { Period } \boldsymbol{t} \\
\text { (State in 1994 or 1996 or 1998) } \\
\end{array}$} \\
\hline & & \multicolumn{3}{|c|}{ Employees } & \multirow{2}{*}{$\begin{array}{l}\text { Appren- } \\
\text { tice }\end{array}$} & \multirow{2}{*}{$\begin{array}{l}\text { Unem- } \\
\text { ployed }\end{array}$} & \multirow{2}{*}{$\begin{array}{c}\begin{array}{c}\text { Out of the } \\
\text { labor } \\
\text { force }\end{array} \\
\end{array}$} \\
\hline & & $\begin{array}{c}\text { High } \\
\text { paid }\end{array}$ & $\begin{array}{l}\text { Low } \\
\text { paid }\end{array}$ & $\begin{array}{c}\text { No } \\
\text { report }\end{array}$ & & & \\
\hline \multicolumn{8}{|l|}{ 2/3 median } \\
\hline \multirow[t]{2}{*}{ Men } & High-paid & 83.7 & 9.1 & 2.6 & 0.3 & 1.6 & 2.8 \\
\hline & Low-paid & 38.8 & 18.3 & 32.7 & 3.6 & 2.2 & 4.4 \\
\hline \multirow[t]{2}{*}{ Women } & High-paid & 71.8 & 13.0 & 6.3 & 0.2 & 1.7 & 7.1 \\
\hline & Low-paid & 27.0 & 18.0 & 37.7 & 1.1 & 4.4 & 11.7 \\
\hline \multicolumn{8}{|l|}{ CHF 3'000 } \\
\hline \multirow[t]{2}{*}{ Men } & High-paid & 84.2 & 9.2 & 1.8 & 0.3 & 1.6 & 2.8 \\
\hline & Low-paid & 37.1 & 22.3 & 29.4 & 4.7 & 1.9 & 4.7 \\
\hline \multirow[t]{2}{*}{ Women } & High-paid & 72.6 & 13.0 & 4.8 & 0.2 & 2.1 & 7.3 \\
\hline & Low-paid & 31.1 & 20.6 & 30.5 & 1.3 & 3.5 & 13.1 \\
\hline \multicolumn{8}{|l|}{$1 / 2$ median } \\
\hline \multirow[t]{2}{*}{ Men } & High-paid & 84.4 & 9.4 & 1.3 & 0.4 & 1.6 & 2.9 \\
\hline & Low-paid & 39.5 & 24.9 & 23.6 & 5.6 & 2.1 & 4.3 \\
\hline \multirow[t]{2}{*}{ Women } & High-paid & 73.7 & 13.3 & 3.0 & 0.2 & 2.2 & 7.5 \\
\hline & Low-paid & 36.4 & 23.6 & 19.5 & 2.1 & 3.5 & 14.9 \\
\hline
\end{tabular}

Note: The sample consists of 11,109 individuals, aged between 15 and 65 years. These individuals represent a subset of the initial sample of 19,636 individuals. Hourly wages below CHF 5 and above CHF 500 have been discarded.

From Table 3 we can see that between roughly 27 and 40 percent of the initially low-paid workers (male and female) succeed in escaping the low-pay segment over a two year period and that only between 18 and about 25 percent remain low-paid over two years. Women have yet always a slightly lower probability of escaping low-paid jobs. Interestingly, the probability to remain high paid amounts to about 84 percent for male workers, while it is roughly 72 percent for female workers. For a considerably large share of those workers initially low-paid, earnings are not reported the subsequent period (third column). It is also revealed that low-paid persons tend to begin an apprenticeship more often than high-paid ones. Since we do not control for age and other characteristics apart from gender, this may be explained by the high-paid workers being in a different phase of their working life compared to the low-paid ones. A remarkable result, moreo- 
ver, is that the probability of an initially low-paid person to drop out of the labor force is almost twice that of an initially high-paid one and that the exit rate is also about twice as high for female workers compared to male workers. The same holds for transitions into unemployment. While the higher exit rate of women may be mainly due to a voluntary retreat from the labor market, for instance to rear children and raise a family, the larger share of transitions into unemployment may be indicative of a generally lower job security or involuntary labor supply adjustments. All in all, these results indicate a higher occupational mobility of women compared to men.

In the empirical part of the paper (Section 4), we will restrict attention to those persons in employment and reporting a wage in every period considered. Therefore, only movements depicted by the first two columns of Table 3 will be considered. This reduces the sample size to 7,617 individuals (restricted sample). ${ }^{5}$ The other movements should nevertheless be kept in mind when discussing the following results.

\section{An Aggregate Transition Matrix}

In order to give a first impression of the extent of the intradistributional dynamics of those in employment and reporting a wage, we have computed a simple transition matrix (Table 4). Each cell in the matrix contains the conditional probability of being in state $i$ in period $t$ provided the state occupied in period $t-1$ was $j .^{6}$ The elements are thus given by the transition probabilities $\operatorname{Pr}\left(y_{t}=i \mid y_{t-1}=j\right)=p_{i j}$ for $t \in\{1994,1996,1998\}$. The income range has been partitioned into deciles in each consecutive period.

What catches the eye is that the diagonal elements representing the stayer probabilities always exceed the off-diagonal elements in magnitude. The largest stayer probabilities are observed at the tails of the wage distribution. At the lowest end of the wage distribution approximately 56 percent of the workers initially low-paid remain low-paid two years later, while at the opposite extreme of the wage distribution the share of the stayers amounts to 62 percent. Mobility increases yet towards the middle range of the distribution. For example of those workers initially in the $5^{\text {th }}$ decile, 36 percent move up the distribution and approximately the same amount move down. The matrix also shows that there are positive probabilities for transitions from the lowest to the highest decile and vice versa. However, the probabilities of making larger jumps than just one decile are generally small and decreasing the wider the jump is. When interpreting these results one has, however, to bear in mind that since the wage distribution is skewed, the absolute wage

\footnotetext{
${ }^{5}$ From initially 11,109 persons we subtracted 2,187 individuals who were not wage earners in year $t$, and 1,305 observations that were corresponding to a second initial period for the same individual. Because the panel covers some persons over a five year period, 686 individuals were simultaneously included in the first two sub-panels and 619 in the last two sub-panels.

${ }^{6}$ The estimation of transition probabilities may be obtained by maximizing a likelihood function (see ANDERSON and GOODMAN 1957).The underlying assumption is that the transition matrix arises from a homogenous first-order Markov probability process. For further details about the computation of transition matrices refer to SHORROCKS $(1976,1978)$ or BARTHOLOMEW (1967).
} 
range is higher in the upper part of the distribution than in the lower part (i.e. the distance measured in CHF between the thresholds is not uniform across the distribution).

Table 4: Transition Matrix; Pooled Data

\begin{tabular}{|c|c|c|c|c|c|c|c|c|c|c|c|}
\hline & \multicolumn{10}{|c|}{ Period $t$} \\
\hline & & $\begin{array}{c}1^{\text {st }} \\
\text { decile }\end{array}$ & $\begin{array}{c}2^{\text {nd }} \\
\text { decile }\end{array}$ & $\begin{array}{c}3^{\text {rd }} \\
\text { decile }\end{array}$ & $\begin{array}{c}4^{\text {th }} \\
\text { decile }\end{array}$ & $\begin{array}{c}5^{\text {th }} \\
\text { decile }\end{array}$ & $\begin{array}{c}6^{\text {th }} \\
\text { decile }\end{array}$ & $\begin{array}{c}7^{\text {th }} \\
\text { decile }\end{array}$ & $\begin{array}{c}8^{\text {th }} \\
\text { decile }\end{array}$ & $\begin{array}{c}9^{\text {th }} \\
\text { decile }\end{array}$ & $\begin{array}{c}10^{\text {th }} \\
\text { decile }\end{array}$ \\
\hline \multirow{10}{*}{ 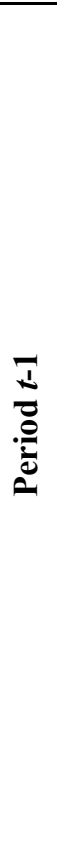 } & $1^{\text {st }}$ decile & $\begin{array}{l}56.3 \\
(1.7)\end{array}$ & $\begin{array}{c}19.7 \\
(1.3)\end{array}$ & $\begin{array}{c}8.4 \\
(0.9) \\
\end{array}$ & $\begin{array}{c}3.9 \\
(0.6)\end{array}$ & $\begin{array}{c}2.3 \\
(0.5)\end{array}$ & $\begin{array}{c}1.7 \\
(0.4)\end{array}$ & $\begin{array}{c}2.3 \\
(0.5)\end{array}$ & $\begin{array}{c}1.2 \\
(0.4)\end{array}$ & $\begin{array}{c}1.6 \\
(0.4)\end{array}$ & $\begin{array}{c}2.6 \\
(0.5)\end{array}$ \\
\hline & $2^{\text {nd }}$ decile & $\begin{array}{c}19.1 \\
(1.3)\end{array}$ & $\begin{array}{l}40.9 \\
(1.6)\end{array}$ & $\begin{array}{l}18.0 \\
1.3)\end{array}$ & $\begin{array}{c}8.8 \\
(0.9)\end{array}$ & $\begin{array}{c}4.2 \\
(0.7)\end{array}$ & $\begin{array}{c}2.7 \\
(0.5)\end{array}$ & $\begin{array}{c}1.4 \\
(0.4)\end{array}$ & $\begin{array}{c}1.2 \\
(0.4)\end{array}$ & $\begin{array}{c}1.2 \\
(0.4)\end{array}$ & $\begin{array}{c}2.5 \\
(0.5)\end{array}$ \\
\hline & $3^{\text {rd }}$ decile & $\begin{array}{c}7.5 \\
(0.9)\end{array}$ & $\begin{array}{l}17.1 \\
(1.3)\end{array}$ & $\begin{array}{l}32.7 \\
(1.6)\end{array}$ & $\begin{array}{l}18.3 \\
(1.3)\end{array}$ & $\begin{array}{l}11.8 \\
(1.1)\end{array}$ & $\begin{array}{c}5.6 \\
(0.8)\end{array}$ & $\begin{array}{c}2.8 \\
(0.6)\end{array}$ & $\begin{array}{c}1.1 \\
(0.4)\end{array}$ & $\begin{array}{c}1.3 \\
(0.4)\end{array}$ & $\begin{array}{c}1.8 \\
(0.4)\end{array}$ \\
\hline & $4^{\text {th }}$ decile & $\begin{array}{c}4.4 \\
(0.7)\end{array}$ & $\begin{array}{c}8.5 \\
(0.9)\end{array}$ & $\begin{array}{l}19.1 \\
(1.3)\end{array}$ & $\begin{array}{l}27.6 \\
(1.5)\end{array}$ & $\begin{array}{l}20.8 \\
(1.4)\end{array}$ & $\begin{array}{l}10.2 \\
(1.0)\end{array}$ & $\begin{array}{c}4.8 \\
(0.7)\end{array}$ & $\begin{array}{c}2.0 \\
(0.5)\end{array}$ & $\begin{array}{c}0.6 \\
(0.3)\end{array}$ & $\begin{array}{c}1.9 \\
(0.5)\end{array}$ \\
\hline & $5^{\text {th }}$ decile & $\begin{array}{c}2.7 \\
(0.5)\end{array}$ & $\begin{array}{c}4.6 \\
(0.7)\end{array}$ & $\begin{array}{c}8.9 \\
(1.0)\end{array}$ & $\begin{array}{l}21.6 \\
(1.4)\end{array}$ & $\begin{array}{l}25.8 \\
(1.5)\end{array}$ & $\begin{array}{l}18.8 \\
(1.3)\end{array}$ & $\begin{array}{c}10.3 \\
(1.0)\end{array}$ & $\begin{array}{c}4.5 \\
(0.7)\end{array}$ & $\begin{array}{c}1.9 \\
(0.5)\end{array}$ & $\begin{array}{c}0.9 \\
(0.3)\end{array}$ \\
\hline & $6^{\text {th }}$ decile & $\begin{array}{c}2.8 \\
(0.6) \\
\end{array}$ & $\begin{array}{c}2.1 \\
(0.5) \\
\end{array}$ & $\begin{array}{c}4.7 \\
(0.7)\end{array}$ & $\begin{array}{c}9.5 \\
(1.0) \\
\end{array}$ & $\begin{array}{l}19.4 \\
(1.3)\end{array}$ & $\begin{array}{l}29.8 \\
(1.5)\end{array}$ & $\begin{array}{l}18.7 \\
(1.3)\end{array}$ & $\begin{array}{c}8.0 \\
(0.9) \\
\end{array}$ & $\begin{array}{c}2.6 \\
(0.5)\end{array}$ & $\begin{array}{c}2.4 \\
(0.5) \\
\end{array}$ \\
\hline & $7^{\text {th }}$ decile & $\begin{array}{c}1.5 \\
(0.4)\end{array}$ & $\begin{array}{c}2.1 \\
(0.5)\end{array}$ & $\begin{array}{c}2.7 \\
(0.5)\end{array}$ & $\begin{array}{c}4.4 \\
(0.7)\end{array}$ & $\begin{array}{c}8.4 \\
(0.9)\end{array}$ & $\begin{array}{l}19.7 \\
(1.3)\end{array}$ & $\begin{array}{l}29.6 \\
(1.5)\end{array}$ & $\begin{array}{l}22.5 \\
(1.4)\end{array}$ & $\begin{array}{c}6.8 \\
(0.8)\end{array}$ & $\begin{array}{c}2.3 \\
(0.5)\end{array}$ \\
\hline & $8^{\text {th }}$ decile & $\begin{array}{c}1.8 \\
(0.4) \\
\end{array}$ & $\begin{array}{c}1.3 \\
(0.4) \\
\end{array}$ & $\begin{array}{c}1.2 \\
(0.4)\end{array}$ & $\begin{array}{c}2.1 \\
(0.5)\end{array}$ & $\begin{array}{c}3.7 \\
(0.6)\end{array}$ & $\begin{array}{c}7.2 \\
(0.9) \\
\end{array}$ & $\begin{array}{l}21.0 \\
(1.4)\end{array}$ & $\begin{array}{l}35.0 \\
(1.6)\end{array}$ & $\begin{array}{l}20.7 \\
(1.4)\end{array}$ & $\begin{array}{c}5.9 \\
(0.8) \\
\end{array}$ \\
\hline & $9^{\text {th }}$ decile & $\begin{array}{c}1.7 \\
(0.4)\end{array}$ & $\begin{array}{c}1.3 \\
(0.4)\end{array}$ & $\begin{array}{c}1.1 \\
(0.4)\end{array}$ & $\begin{array}{c}2.1 \\
(0.5)\end{array}$ & $\begin{array}{c}1.3 \\
(0.4)\end{array}$ & $\begin{array}{c}1.5 \\
(0.4)\end{array}$ & $\begin{array}{c}6.4 \\
(0.8)\end{array}$ & $\begin{array}{l}21.2 \\
(1.4)\end{array}$ & $\begin{array}{l}45.5 \\
(1.7)\end{array}$ & $\begin{array}{c}17.8 \\
(1.3)\end{array}$ \\
\hline & $10^{\text {th }}$ decile & $\begin{array}{c}2.7 \\
(0.5)\end{array}$ & $\begin{array}{c}1.9 \\
(0.5)\end{array}$ & $\begin{array}{c}3.1 \\
(0.6)\end{array}$ & $\begin{array}{c}1.7 \\
(0.4)\end{array}$ & $\begin{array}{c}2.2 \\
(0.5)\end{array}$ & $\begin{array}{c}2.8 \\
(0.6)\end{array}$ & $\begin{array}{c}2.7 \\
(0.5)\end{array}$ & $\begin{array}{c}3.3 \\
(0.6)\end{array}$ & $\begin{array}{l}17.7 \\
(1.3)\end{array}$ & $\begin{array}{l}61.9 \\
(1.6)\end{array}$ \\
\hline
\end{tabular}

Note: Standard Errors are given in parenthesis. The numbers are expressed in percentage points.

\section{International Comparison}

An important question within this context is whether the level and pattern of aggregate mobility in Switzerland is similar to that in other countries. DICKENS (2000), for instance, using two data sets for Great Britain found qualitatively similar results to ours for one year movements within the wage distribution: a pronounced mobility in the middle range of the distribution, and a higher persistence in the lowest and highest deciles of the distribution. When investigating three-year and five-year transitions, he found a higher mobility. The probability of remaining in the lowest decile drops from 35 percent over a one-year period to 20 percent over a five-year period. This increased mobility when the period of observation is extended arises because one usually faces censored spells. When extending the period of observation, one can relax the cross-sectional nature of the survey and therefore higher mobility is observed (see BANE and ELWOOD 1983, and SHELDON 1991).

International comparisons have been conducted by MAîTRE and NOLAN (2000), who used the European Community Census Survey and calculated the extent of mobility across quintiles for the year 1994 and 1995 in 12 European countries. We have calculated a similar transition matrix with our data based on quintiles as well (not shown here), and found that roughly 58 percent of individuals stayed two consecutive years in the 
same quintile over the period 1992-1998. ${ }^{7}$ The share of individuals moving up or down by one quintile amounts to 32 percent. The share of individuals moving up or down by two and more quintiles, finally, amounts to 10 percent. Taking the results of MAÎTRE and NOLAN as a reference point, this situates Switzerland at rank 6, 7 and 8 for the stayers, for those moving by one quintile, and for those moving more than one quintile respectively (with rank one being the most immobile country). Further comparisons can be drawn with OECD countries where the transition probabilities from the lowest quintile to the next higher one vary between 16 percent in the USA (lowest) and 27 percent in the UK (highest) over a five year period (OECD 1996). Transitions from the lowest to either the second or the third quintile for full-time workers vary between 11 (USA) and 24 (UK) percent. ${ }^{8}$ In our sample, four percent of the individuals jump from the lowest quintiles to the next higher one over a three year period (full and part-time workers). Following these comparisons, one can thus reasonably consider Switzerland as being characterized by a slightly lower wage mobility compared to most European Union countries. We should, however, stress that these results are to be interpreted with caution because the data and the definitions of low pay are not always entirely comparable.

The remainder of this paper now addresses the question of whether being low-paid in the first period implies a higher probability of being low-paid the next period compared to being high-paid initially. As mentioned earlier, this question is directly related to the issue of state dependence and heterogeneity. The aggregate transition probabilities in Table 4 may, on the one hand, result from worker's heterogeneity, with the personal characteristics determining the low-pay status over time. In this sense state dependence may be observed at an aggregate level even though it is absent at the individual level, i.e. occupying a low-pay state does not necessarily increase the probability of being low-paid in the future. On the other hand, the stayer probabilities may be generated by state dependence, with the experience of low-pay modifying individual tastes or constraints and producing per se a higher persistence probability, regardless of the individual characteristics (CAPELLARI 1999). Movements into and out of low-paid employment thus cannot simply be characterized either as a stepping-stone into a more stable and higher-paid career or as a permanent trap. Rather the relative importance of both these effects needs to be assessed empirically. Disentangling between heterogeneity and state dependence is thus a highly relevant issue in the analysis of low-pay transitions as they imply different strategies to help individuals moving out of low-pay employment. In the next section we propose a formal model describing the persistence of individual low-paid labor market experiences that enables us to assess the different determinants.

\footnotetext{
${ }^{7}$ These 58 percent correspond to the sum of those remaining on the diagonal of the transition matrix relative to the entire sample.

${ }^{8}$ Wage mobility is seen as one crucial prerogative of labor market flexibility. It therefore comes as quite a surprise that in international comparisons the US hardly ever ranks first. Rigidity is found to be highest in Italy, where almost 44 percent of workers remain in the first quintile over five years. Germany, in turn, figures first with only 27 percent remaining low-paid. However, in Germany many low-paid workers leave the labor market within a five year period.
} 


\section{The Econometric Model}

This section summarizes the approach suggested by STEWART and SWAFFIELD (1999) for studying individual earnings mobility. The first ingredient of the model consists in defining the initial period probability of being low paid. Denote by $\lambda_{t-1}$ the low pay threshold and define an indicator variable $y$ as follows:

$$
y_{t-1}=\left\{\begin{array}{ll}
1, & \text { if } y_{t-1}^{*}<\lambda_{t-1} \\
0, & \text { if } y_{t-1}^{*} \geq \lambda_{t-1}
\end{array} .\right.
$$

$y^{*}{ }_{t-1}$ is defined as the hourly wage of part-time or full time workers. The probability of being low-paid in period $t-1$ is then given by the probit equation

$$
\operatorname{Pr}\left(y_{i t-1}=1\right)=\Phi\left(x_{i t-1}^{\prime} \beta\right),
$$

where $\Phi$ denotes the standard normal cumulative distribution function, $x_{i t-1}$ is a vector of covariates explaining the earnings of individual $i$, and $\beta$ is the vector of slope coefficients. Since (1) is a simple probit equation the error term is distributed as $\varepsilon_{t-1} \sim N(0,1)$. Next suppose that earnings of an individual in period $t$ depend on whether or not he was low-paid in period $t$ - 1 . Suppose further that if $y_{i t-1}=1$, the process may be described by

$$
\operatorname{Pr}\left(y_{i t}=1\right)=\Phi\left(z_{i t}^{\prime} \gamma\right)
$$

with $y_{t}$ defined similarly to $y_{t-1}$. For those individuals with a $y_{i t-1}=0$ the $\gamma$-vector may differ. However, even though the process in (2) is only defined for those individuals with $y_{i t-1}=1$, we still maintain the assumption that the distribution of $\varepsilon_{t}$ is defined over all individuals. From this it follows that the distribution of $\left(\varepsilon_{t-1}, \varepsilon_{t}\right)$ is bivariate standard normal with correlation $\rho$

$$
\left[\begin{array}{c}
\varepsilon_{t-1} \\
\varepsilon_{t}
\end{array}\right] \sim N\left[\left(\begin{array}{l}
0 \\
0
\end{array}\right),\left(\begin{array}{ll}
1 & \rho \\
\rho & 1
\end{array}\right)\right] .
$$

Accordingly, the probability of individual $i$ being low-paid in both periods is given by the joint distribution

$$
\operatorname{Pr}\left(y_{t-1}=1, y_{t}=1\right)=\Phi_{2}\left(x_{i t-1}^{\prime} \beta, z_{i t}^{\prime} \gamma ; \rho\right),
$$

where $\Phi_{2}$ is the cumulative of the bivariate normal distribution. The conditional distribution $\operatorname{Pr}\left(y_{t}=1 \mid y_{t-1}=1\right)$, finally, is obtained by dividing the joint distribution by the marginal distribution according to

$$
\operatorname{Pr}\left(y_{t}=1 \mid y_{t-1}=1\right)=\frac{\Phi_{2}\left(x_{i t-1}^{\prime} \beta, z_{i t}^{\prime} \gamma ; \rho\right)}{\Phi\left(x_{i t-1}^{\prime} \beta\right)} .
$$

\footnotetext{
9 The likelihood function for individual $i$ being low paid in year $t-1$ is given by $L^{1}=\Phi_{2}\left(\gamma^{\prime} z_{t}, \beta^{\prime} x_{t-1} ; \rho\right)^{\left(y_{t} y_{t-1}\right)} \Phi_{2}\left(-\gamma^{\prime} z_{t}, \beta^{\prime} x_{t-1} ;-\rho\right)^{\left(1-y_{t}\right) y_{t-1}} \Phi\left(-\beta^{\prime} x_{t-1}\right)^{\left(1-y_{t-1}\right)}$. This likelihood function reflects the
} 
Several comments about this econometric model can be made:

i) The model takes care of the initial conditions problem mentioned by HECKMAN (1981). He showed that ignoring the correlation between the initial state and the subsequent transitions and computing a simple probit model leads to a sample selection bias if the coefficient $\rho$ is significantly different from zero. Clearly, the wage process started prior to the sampling period and its initial conditions are not observable. Hence due to serial correlation in such a process the "randomly" chosen initial period and the wage state associated with it requires that it is endogenized along the lines set out above. ${ }^{10}$ The initial condition problem might be neglected when the panel covers a long enough time horizon because the correlation steadily declines over time and eventually fades out. A short panel over few years, however, imperatively requires controlling for the initial selection into a particular state.

ii) For the parameter vector to be identified, some variables included in $x_{i t-1}$ must be excluded from $z_{i t}$. STEWART and SWAFFIELD (1999), for instance, have included family background variables in the vector $x_{i t-1}$, which are not included in the vector $z_{i t}$. The idea of using family background variables rests on the assumption that equation (1) reflects the selection into a particular state in the initial period - a selection that may indeed be highly dependent on inherited parental characteristics. Since the Swiss Labor Force Survey provides no such information we have used information on the nationality, the complementary income, and a dummy variable for children. Additionally, the squared age proxying for labor market experience of a worker is included in $x_{i t-1}$, but not in $z_{i t}$. The extra variables in $x_{i t-1}$ can therefore be viewed as instruments for the endogenous selection into the initial state. The underlying assumption is that they do not affect the probability of being low-paid, given the state in the previous period: they affect the level of the low-pay status variable, but not the change. The vector $z_{i t}$, by contrast, should contain variables that explain wage changes. A LR-test is carried out to check for the validity of the instruments.

iii) Notice that if the initial state is uncorrelated with subsequent transitions, then it suffices to run a simple probit estimation for the year $t$ selecting only those individuals that were low paid in period $t-1$. This is to say that if the $\rho$ is equal to zero, the probability of being low paid in year $t$ conditional on being low-paid in year $t-1$ simplifies to

$$
\operatorname{Pr}\left(y_{t}=1 \mid y_{t-1}=1\right)=\Phi\left(z_{i t}^{\prime} \gamma\right) .
$$

This, subsequently allows for a formal test of whether there is serial correlation in the wage process or whether the initial state may be treated as exogenous.

partial observability assumption in the bivariate probit model, i.e. individuals high-paid in period $t$-1are treated as if they were not available to us in period $t$ (see MENG and SCHMIDT 1985).

${ }^{10}$ The true initial state of the wage process will be embedded in the wage levels in each period, causing lagged wages to be endogenous with respect to current wages. 
It remains to be mentioned that a similar model to (3) can be constructed for those individuals that were high paid in period $t$-1, i.e. one can estimate the $\operatorname{Pr}\left(y_{t}=1 \mid y_{t-1}=0\right)$ the same way as described above. This equation then captures the probability of dropping into the low-wage segment given the job in the previous period was high paid. ${ }^{11}$

\section{Results}

The results are reported in two steps. We first discuss the low-pay incidence for the period $t-1$. The determinants of low pay in the period $t-1$ are then used as the selection equation for the endogenous selection model. The results of this transition model are reported subsequently. Remember that the transitions always comprise moves over two years (between 1992 and 1994, between 1994 and 1996, and between 1996 and 1998) in the sequel.

\section{Low-Pay Incidence}

Table 5 shows the estimation results of the simple probit model of the low-pay incidence in period $t-1$ (1992, 1994 and 1996, pooled) for the three different low-pay thresholds. The dummy variables for the firm size are defined against a medium firm size between 20 and 100 employees, the employment status is defined against middle managers, and the sectorial dummy variables are defined against manufacturing. Apart from the coefficient estimates associated with the variable we also report the marginal effects. For the variables education and experience the marginal effects are computed as the difference between the probabilities with 9 and with 12 years of schooling and between the age of 35 and 40 years respectively (see STEWART and SWAFFIELD 1999 for further details). For the dummy variables the marginal effects return the change of the probability associated with a switch from 0 to 1 .

\footnotetext{
${ }^{11}$ The likelihood function in this case is given by $L^{2}=\Phi_{2}\left(-\gamma^{\prime} z_{t},-\beta^{\prime} x_{t-1} ; \rho\right)^{\left(1-y_{t}\right)\left(1-y_{t-1}\right)} \Phi_{2}\left(\gamma^{\prime} z_{t},-\beta^{\prime} x_{t-1} ;-\rho\right)^{\left(1-y_{t-1}\right) y_{t}} \Phi\left(\beta^{\prime} x_{t-1}\right)^{y_{t-1}}$.
} 
Table 5: Low-Pay Incidence in Period t-1

\begin{tabular}{|c|c|c|c|c|}
\hline \multicolumn{2}{|l|}{ Threshold } & \multirow{2}{*}{$\begin{array}{c}\mathbf{2 / 3} \text { median } \\
3.326 \\
(0.218)\end{array}$} & \multirow{2}{*}{$\begin{array}{c}\text { CHF 3,000 } \\
2.252 \\
(0.234)\end{array}$} & \multirow{2}{*}{$\begin{array}{c}1 / 2 \text { median } \\
1.474 \\
(0.260)\end{array}$} \\
\hline Constant & & & & \\
\hline \multirow[t]{8}{*}{$\begin{array}{l}\text { Personal charac- } \\
\text { teristics }\end{array}$} & Male & $\begin{array}{c}-0.530 \\
(0.039) \\
-0.107\end{array}$ & $\begin{array}{c}-0.473 \\
(0.045) \\
-0.063\end{array}$ & $\begin{array}{c}-0.304 \\
(0.052) \\
-0.025\end{array}$ \\
\hline & Married & $\begin{array}{c}-0.002 \\
(0.039) \\
0.000\end{array}$ & $\begin{array}{c}0.009 \\
(0.043) \\
0.001\end{array}$ & $\begin{array}{c}0.002 \\
(0.051) \\
0.000\end{array}$ \\
\hline & Education & $\begin{array}{c}-0.094 \\
(0.008) \\
-0.073 \\
\end{array}$ & $\begin{array}{c}-0.077 \\
(0.009) \\
-0.040 \\
\end{array}$ & $\begin{array}{c}-0.071 \\
(0.010) \\
-0.024 \\
\end{array}$ \\
\hline & Age & $\begin{array}{c}-0.123 \\
(0.010) \\
-0.145\end{array}$ & $\begin{array}{c}-0.103 \\
(0.011) \\
-0.082\end{array}$ & $\begin{array}{l}-0.095 \\
(0.013) \\
-0.049\end{array}$ \\
\hline & $\mathrm{Age}^{2} / 100$ & $\begin{array}{c}0.141 \\
(0.013) \\
0.028\end{array}$ & $\begin{array}{c}0.121 \\
(0.013) \\
0.018\end{array}$ & $\begin{array}{c}0.112 \\
(0.015) \\
0.011\end{array}$ \\
\hline & Children & $\begin{array}{c}0.049 \\
(0.039) \\
0.010 \\
\end{array}$ & $\begin{array}{c}0.073 \\
(0.044) \\
0.009 \\
\end{array}$ & $\begin{array}{c}0.101 \\
(0.050) \\
0.008 \\
\end{array}$ \\
\hline & Swiss Nationality & $\begin{array}{c}-0.288 \\
(0.043) \\
-0.063\end{array}$ & $\begin{array}{c}-0.195 \\
(0.049) \\
-0.027\end{array}$ & $\begin{array}{c}-0.076 \\
(0.059) \\
-0.006\end{array}$ \\
\hline & $\begin{array}{l}\text { Other Household } \\
\text { Income/100,000 }\end{array}$ & $\begin{array}{c}0.003 \\
(0.012) \\
0.001\end{array}$ & $\begin{array}{c}0.015 \\
(0.012) \\
0.002\end{array}$ & $\begin{array}{c}0.015 \\
(0.014) \\
0.002\end{array}$ \\
\hline City & $\begin{array}{l}>30,000 \text { Inhabi- } \\
\text { tants }\end{array}$ & $\begin{array}{c}-0.172 \\
(0.041) \\
-0.031\end{array}$ & $\begin{array}{c}-0.165 \\
(0.047) \\
-0.020\end{array}$ & $\begin{array}{l}-0.183 \\
(0.056) \\
-0.013\end{array}$ \\
\hline \multirow[t]{2}{*}{ Firm size } & $<20$ & $\begin{array}{c}0.304 \\
(0.039) \\
0.061\end{array}$ & $\begin{array}{c}0.327 \\
(0.044) \\
0.044\end{array}$ & $\begin{array}{c}0.325 \\
(0.051) \\
0.028\end{array}$ \\
\hline & $>100$ & $\begin{array}{c}-0.241 \\
(0.046) \\
-0.044\end{array}$ & $\begin{array}{c}-0.283 \\
(0.054) \\
-0.034\end{array}$ & $\begin{array}{c}-0.288 \\
(0.066) \\
-0.021\end{array}$ \\
\hline \multirow[t]{2}{*}{$\begin{array}{l}\text { Employment } \\
\text { status }\end{array}$} & Employee & $\begin{array}{c}0.130 \\
(0.040) \\
0.025\end{array}$ & $\begin{array}{c}0.090 \\
(0.046) \\
0.011\end{array}$ & $\begin{array}{c}0.095 \\
(0.053) \\
0.007\end{array}$ \\
\hline & Manager & $\begin{array}{c}-0.299 \\
(0.073) \\
-0.050 \\
\end{array}$ & $\begin{array}{c}-0.297 \\
(0.083) \\
-0.032 \\
\end{array}$ & $\begin{array}{c}-0.220 \\
(0.097) \\
-0.015 \\
\end{array}$ \\
\hline \multirow[t]{6}{*}{ Sector } & Primary sector & $\begin{array}{c}1.067 \\
(0.098) \\
0.327\end{array}$ & $\begin{array}{c}0.991 \\
(0.101) \\
0.231\end{array}$ & $\begin{array}{c}0.966 \\
(0.108) \\
0.163\end{array}$ \\
\hline & Construction & $\begin{array}{c}-0.392 \\
(0.080) \\
-0.061\end{array}$ & $\begin{array}{c}-0.348 \\
(0.093) \\
-0.035\end{array}$ & $\begin{array}{c}-0.330 \\
(0.111) \\
-0.020\end{array}$ \\
\hline & $\begin{array}{l}\text { Wholesale/ Retail } \\
\text { Trade/ Repair }\end{array}$ & $\begin{array}{c}0.234 \\
(0.051) \\
0.050\end{array}$ & $\begin{array}{c}0.246 \\
(0.057) \\
0.035\end{array}$ & $\begin{array}{c}0.147 \\
(0.067) \\
0.013\end{array}$ \\
\hline & $\begin{array}{l}\text { Restaurants/ } \\
\text { Hotels }\end{array}$ & $\begin{array}{c}0.686 \\
(0.092) \\
0.186\end{array}$ & $\begin{array}{c}0.451 \\
(0.098) \\
0.078\end{array}$ & $\begin{array}{c}0.341 \\
(0.112) \\
0.036\end{array}$ \\
\hline & $\begin{array}{l}\text { Transport/ Com- } \\
\text { munication }\end{array}$ & $\begin{array}{c}-0.412 \\
(0.078) \\
-0.064\end{array}$ & $\begin{array}{c}-0.538 \\
(0.101) \\
-0.048\end{array}$ & $\begin{array}{c}-0.407 \\
(0.117) \\
-0.024\end{array}$ \\
\hline & Bank/ Insurance & -0.597 & -0.752 & -0.621 \\
\hline
\end{tabular}




\begin{tabular}{|c|c|c|c|c|}
\hline & & $\begin{array}{l}(0.090) \\
-0.083\end{array}$ & $\begin{array}{l}(0.123) \\
-0.058\end{array}$ & $\begin{array}{l}(0.148) \\
-0.031\end{array}$ \\
\hline & $\begin{array}{l}\text { Other Business } \\
\text { Services }\end{array}$ & $\begin{array}{c}-0.384 \\
(0.049) \\
-0.069\end{array}$ & $\begin{array}{c}-0.302 \\
(0.056) \\
-0.036\end{array}$ & $\begin{array}{l}-0.205 \\
(0.066) \\
-0.015\end{array}$ \\
\hline & Personal Services & $\begin{array}{c}0.060 \\
(0.072) \\
0.012\end{array}$ & $\begin{array}{c}0.180 \\
(0.077) \\
0.026\end{array}$ & $\begin{array}{c}0.232 \\
(0.087) \\
0.022\end{array}$ \\
\hline & Full-time & $\begin{array}{c}-0.217 \\
(0.041) \\
-0.045\end{array}$ & $\begin{array}{c}-0.251 \\
(0.045) \\
-0.035\end{array}$ & $\begin{array}{c}-0.281 \\
(0.052) \\
-0.025\end{array}$ \\
\hline $\begin{array}{l}\text { Log Likelihood } \\
\text { Pseudo R }{ }^{2} \\
\text { Observed Prob. } \\
\text { Predicted Prob. }\end{array}$ & & $\begin{array}{c}-3941.636 \\
0.2144 \\
0.167 \\
0.114\end{array}$ & $\begin{array}{c}-3053.463 \\
0.2033 \\
0.109 \\
0.064\end{array}$ & $\begin{array}{c}-2184.007 \\
0.1776 \\
0.064 \\
0.036\end{array}$ \\
\hline \multicolumn{5}{|c|}{$\begin{array}{l}\text { Note: Shaded cells denote statistical significance at least at the } 90 \text { percent level. Num- } \\
\text { bers in brackets are the standard errors, numbers in italic represent the marginal effects. } \\
\text { They are calculated as the change in the probability associated with a discrete change of } \\
\text { the dummy variable from } 0 \text { to } 1 \text { evaluated at the mean value of the other variables. For } \\
\text { education the marginal effect is obtained as the change in the probability associated } \\
\text { with a change from } 9 \text { to } 12 \text { years of formal schooling. For experience the marginal } \\
\text { effect is obtained as the change in the probability associated with a change from } 35 \text { to } \\
40 \text { years of age. }\end{array}$} \\
\hline
\end{tabular}

The pattern emerging from these computations confirms to a large extent the existing evidence about lowpay incidence in Switzerland and from standard wage equations (DEUTSCH et al. 1999, LIECHTI and KNÖPFEL 1998). Considering first the personal characteristics it is revealed that male workers experience a lower incidence of low-pay than female workers (between 2 and 10 percent smaller incidence of low-pay). Since we have controlled for most of the relevant characteristics usually seen as influencing individual productivity, this difference may well be taken as a sign of discrimination against female workers. The variables experience and education are statistically significant and their quantitative impact varies depending on the threshold considered. A difference between 9 and 12 years of formal education reduces the low-pay incidence at least by 2.4 and at most by 7.3 percent while a difference between 35 and 40 years of age reduces the low-pay incidence at least by 5 and at most by 14.5 percent on average. The usual result of a concave wage profile is reflected by the positive sign associated with the age squared variable.

The results further show that foreign workers seem more exposed to low-pay employment than Swiss citizens. An exception to this is the lowest threshold considered where the corresponding coefficient is statistically insignificant. ${ }^{12}$ On average, working in an urban area or a city reduces the incidence of low-pay. Working full-time also significantly reduces the low-pay incidence. Compared to manufacturing, those economic sectors exhibiting a higher low-pay incidence are the primary sector, wholesale, retail trade and repair, the personal services as well as restaurants and hotels. Construction workers and bank and insurance

\footnotetext{
${ }^{12}$ This may be due to the fact that the large share of observations which have personal characteristics with a given effect on the low-pay probability is located higher up the wage distribution. Apparently at the lowest tail of the wage distribution nationality is thus not associated systematically with low-pay incidence.
} 
employees and other business services, by contrast, seem less exposed to a low-pay occurrence. The marginal effects of the sectorial dummy variables vary considerably. Working in the primary sector, for instance, increases the low-pay incidence by 16 to 33 percent compared to manufacturing. A similar result holds for the catering business, which exhibits a low-pay incidence that is at most 18 percent larger than in manufacturing. A higher low-pay incidence is also associated with working in a small firm compared to a middle sized firm. This conforms with other studies showing that small firms tend to choose more laborintensive technologies due to scale economies in physical capital and also often make relatively intensive use of low-skilled labor perhaps due to diminishing costs per head as the pool of workers to be trained increases. Working in a larger firm (more than 100 employees) consequently reduces low-pay incidence.

To be married and the complementary household income are found to have no systematic effect on the lowpay probability. One may thus preclude that employers usually set wages without taking into account the broader income and family situation of a worker.

The results obtained so far are very similar to those of international studies on low-pay incidence (see OECD 1996). Based on a cross-country comparison, the OECD as well finds that low-pay is more pronounced for female workers than for male workers, and comparable countries to Switzerland also possess a relatively pronounced low-pay incidence in the wholesale and retail trade, in personal services and restaurant, hotels and catering. One may, for this reason, conclude that the results concerning the low-pay incidence in Switzerland mainly reflect structural reasons shared with other countries rather than cyclical or idiosyncratic effects.

\section{Transition Probabilities}

The next task consists in estimating the coefficients of the transition equation probabilities. In Table 6 , the first six columns show the results for the probability of being low paid in both years, i.e. $\operatorname{Pr}\left(y_{t}=1 \mid y_{t-1}=1\right)$, and the next six give the estimates for the conditional probability of being low paid in period $t$ given the person had a wage above the low-pay threshold in the preceding period $t$-1, i.e. $\operatorname{Pr}\left(y_{t}=1 \mid y_{t-1}=0\right)$. While the former equation measures the probability of remaining in the low-pay state, the latter equation measures the probability of falling under the low-pay threshold. The other transitions, i.e. those from a low-paid job into a higher paid job, and those to remain high paid, of course, are complementary to the transitions reported here.

For both models, we estimate the endogenous selection model and the conditional probit model. This gives an impression of the likely bias resulting when the wage process is serially correlated. Since the coefficients are difficult to interpret the marginal effects are reported as well. They were computed in a way similar as 
before when we looked at the low-pay incidence, and they may directly be interpreted as the percentage change in the probability of remaining low-paid or dropping into the low-pay segment.

First of all we find that the probability of remaining in the low-wage segment given one was low-paid in the previous period varies between 36 and 54 percent, depending on which threshold is considered. This at the same time means that between 56 and 64 percent of those having been low-paid succeeded in escaping the low-pay segment to the next period. The probability of entering the low-pay segment from a higher paid job varies between 3 and almost 5 percent, indicating that once a worker has succeeded in establishing herself in a higher-paid job the probability of dropping obviously becomes relatively small. ${ }^{13}$

Table 6: Transition Probabilities

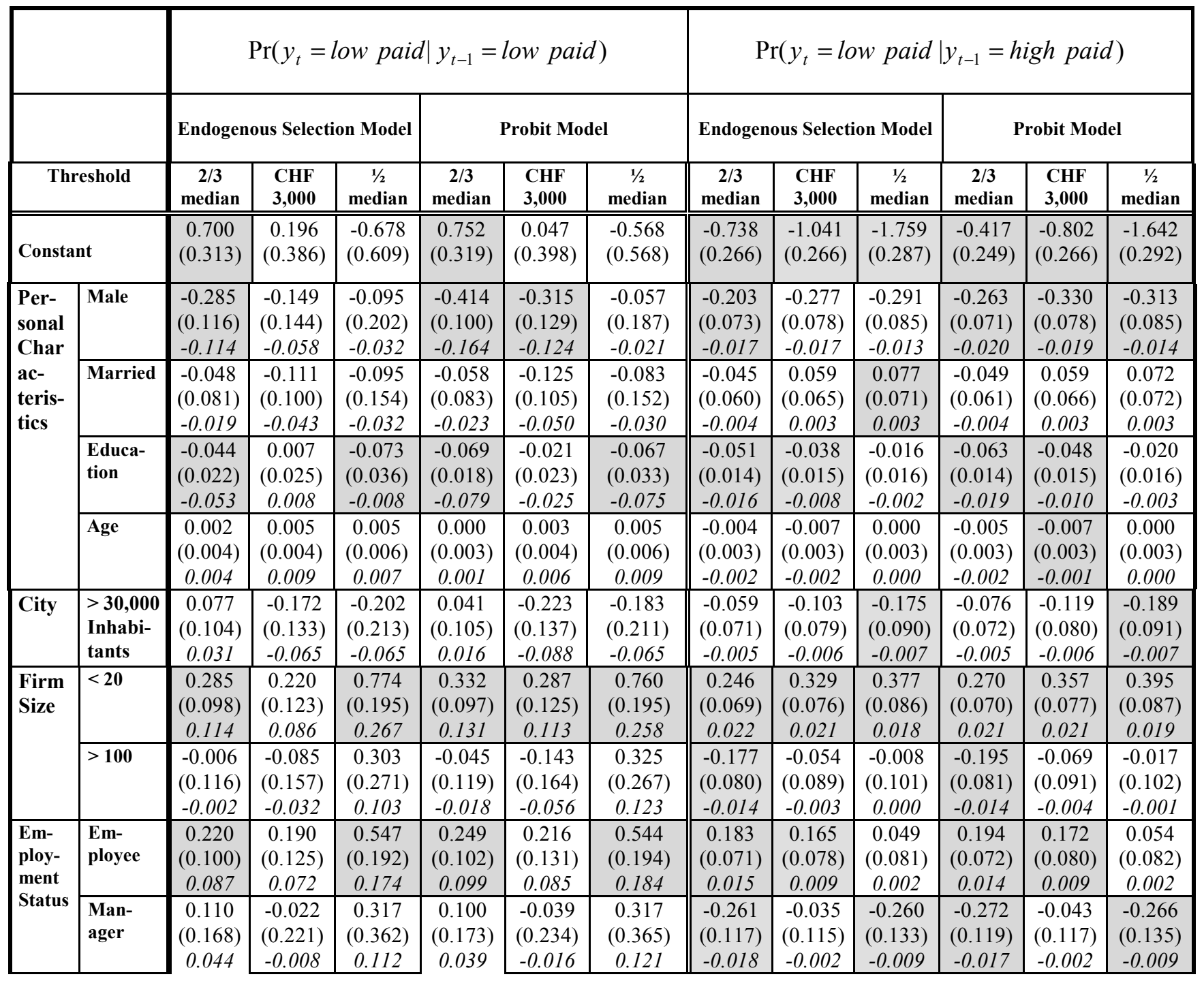

\footnotetext{
${ }^{13}$ These numbers clearly differ from those reported in Table 3 because the sample is restricted to workers reporting a wage and remaining in the labor force over a two year period.
} 


\begin{tabular}{|c|c|c|c|c|c|c|c|c|c|c|c|c|c|}
\hline \multirow[t]{8}{*}{ Sector } & Primary & \begin{tabular}{|c|}
0.096 \\
$(0.229)$ \\
0.039 \\
\end{tabular} & $\begin{array}{c}-0.074 \\
(0.268) \\
-0.028\end{array}$ & $\begin{array}{c}0.033 \\
(0.377) \\
0.011\end{array}$ & $\begin{array}{c}0.324 \\
(0.208) \\
0.125\end{array}$ & $\begin{array}{c}0.219 \\
(0.251) \\
0.087\end{array}$ & $\begin{array}{l}-0.062 \\
(0.318) \\
-0.022\end{array}$ & $\begin{array}{c}0.761 \\
(0.209) \\
0.117\end{array}$ & $\begin{array}{c}0.913 \\
(0.191) \\
0.121\end{array}$ & $\begin{array}{c}0.919 \\
(0.187) \\
0.098\end{array}$ & $\begin{array}{c}0.918 \\
(0.203) \\
0.143\end{array}$ & $\begin{array}{c}1.070 \\
(0.188) \\
0.149\end{array}$ & $\begin{array}{c}1.054 \\
(0.188) \\
0.123\end{array}$ \\
\hline & \begin{tabular}{|l|}
$\begin{array}{l}\text { Con- } \\
\text { struction }\end{array}$ \\
\end{tabular} & \begin{tabular}{|c|}
-0.752 \\
$(0.216)$ \\
-0.253
\end{tabular} & $\begin{array}{c}-0.937 \\
(0.306) \\
-0.266\end{array}$ & $\begin{array}{l}-1.513 \\
(0.565) \\
-0.282\end{array}$ & $\begin{array}{c}-0.846 \\
(0.215) \\
-0.316\end{array}$ & $\begin{array}{c}-1.042 \\
(0.315) \\
-0.344\end{array}$ & $\begin{array}{l}-1.493 \\
(0.567) \\
-0.323\end{array}$ & $\begin{array}{c}0.277 \\
(0.121) \\
0.028\end{array}$ & $\begin{array}{c}0.138 \\
(0.137) \\
0.009\end{array}$ & $\begin{array}{c}0.046 \\
(0.157) \\
0.002\end{array}$ & $\begin{array}{c}0.248 \\
(0.123) \\
0.022\end{array}$ & $\begin{array}{c}0.118 \\
(0.139) \\
0.007\end{array}$ & $\begin{array}{c}0.035 \\
(0.159) \\
0.001\end{array}$ \\
\hline & \begin{tabular}{|l|} 
Whole- \\
sale/ \\
Ret. Tr./ \\
Rep. \\
\end{tabular} & $\begin{array}{c}0.082 \\
(0.121) \\
0.033\end{array}$ & $\begin{array}{c}-0.103 \\
(0.150) \\
-0.039\end{array}$ & $\begin{array}{c}-0.098 \\
(0.235) \\
-0.032\end{array}$ & $\begin{array}{c}0.132 \\
(0.122) \\
0.052\end{array}$ & $\begin{array}{c}-0.031 \\
(0.156) \\
-0.012\end{array}$ & $\begin{array}{c}-0.113 \\
(0.234) \\
-0.041\end{array}$ & $\begin{array}{c}0.384 \\
(0.096) \\
0.040\end{array}$ & $\begin{array}{c}0.411 \\
(0.099) \\
0.032\end{array}$ & $\begin{array}{c}0.321 \\
(0.108) \\
0.018\end{array}$ & $\begin{array}{c}0.417 \\
(0.096) \\
0.040\end{array}$ & $\begin{array}{c}0.440 \\
(0.100) \\
0.032\end{array}$ & $\begin{array}{c}0.331 \\
(0.109) \\
0.018\end{array}$ \\
\hline & $\begin{array}{l}\text { Restau- } \\
\text { rants/ } \\
\text { Hotels }\end{array}$ & $\begin{array}{c}-0.206 \\
(0.190) \\
-0.079 \\
\end{array}$ & $\begin{array}{c}-0.652 \\
(0.232) \\
-0.202 \\
\end{array}$ & $\begin{array}{c}-0.882 \\
(0.393) \\
-0.206 \\
\end{array}$ & $\begin{array}{c}-0.101 \\
(0.190) \\
-0.040 \\
\end{array}$ & $\begin{array}{c}-0.563 \\
(0.242) \\
-0.210 \\
\end{array}$ & $\begin{array}{l}-0.915 \\
(0.386) \\
-0.255 \\
\end{array}$ & $\begin{array}{c}0.899 \\
(0.177) \\
0.151 \\
\end{array}$ & $\begin{array}{c}0.878 \\
(0.166) \\
0.112 \\
\end{array}$ & $\begin{array}{c}0.712 \\
(0.171) \\
0.062 \\
\end{array}$ & $\begin{array}{c}1.021 \\
(0.172) \\
0.170 \\
\end{array}$ & $\begin{array}{c}0.985 \\
(0.164) \\
0.128 \\
\end{array}$ & $\begin{array}{c}0.779 \\
(0.173) \\
0.070 \\
\end{array}$ \\
\hline & \begin{tabular}{|l|} 
Trans./ \\
Com- \\
munica- \\
tion \\
\end{tabular} & $\begin{array}{c}-0.454 \\
(0.208) \\
-0.166\end{array}$ & $\begin{array}{c}-0.406 \\
(0.296) \\
-0.141\end{array}$ & $\begin{array}{c}-0.082 \\
(0.406) \\
-0.027\end{array}$ & $\begin{array}{c}-0.539 \\
(0.210) \\
-0.210\end{array}$ & $\begin{array}{c}-0.536 \\
(0.307) \\
-0.200\end{array}$ & $\begin{array}{c}-0.052 \\
(0.404) \\
-0.019\end{array}$ & $\begin{array}{c}-0.161 \\
(0.142) \\
-0.012\end{array}$ & $\begin{array}{c}-0.276 \\
(0.167) \\
-0.013\end{array}$ & $\begin{array}{c}-0.285 \\
(0.191) \\
-0.010\end{array}$ & $\begin{array}{c}-0.197 \\
(0.143) \\
-0.012\end{array}$ & $\begin{array}{c}-0.316 \\
(0.169) \\
-0.013\end{array}$ & $\begin{array}{c}-0.300 \\
(0.192) \\
-0.010\end{array}$ \\
\hline & $\begin{array}{l}\text { Bank/ } \\
\text { Insur- } \\
\text { ance }\end{array}$ & $\begin{array}{c}-0.581 \\
(0.275) \\
-0.205 \\
\end{array}$ & $\begin{array}{c}-0.447 \\
(0.513) \\
-0.153 \\
\end{array}$ & - & $\begin{array}{c}-0.702 \\
(0.277) \\
-0.268 \\
\end{array}$ & $\begin{array}{c}-0.705 \\
(0.525) \\
-0.253 \\
\end{array}$ & - & $\begin{array}{c}-0.133 \\
(0.149) \\
-0.010 \\
\end{array}$ & $\begin{array}{c}-0.358 \\
(0.186) \\
-0.015 \\
\end{array}$ & $\begin{array}{c}-0.272 \\
(0.197) \\
-0.009 \\
\end{array}$ & $\begin{array}{c}-0.189 \\
(0.150) \\
-0.012 \\
\end{array}$ & $\begin{array}{c}-0.410 \\
(0.189) \\
-0.016 \\
\end{array}$ & $\begin{array}{c}-0.298 \\
(0.199) \\
-0.009 \\
\end{array}$ \\
\hline & $\begin{array}{l}\text { er } \\
\text { ices }\end{array}$ & $\begin{array}{c}-0.309 \\
(0.132) \\
-0.121 \\
\end{array}$ & $\begin{array}{c}-0.382 \\
(0.162) \\
-0.142 \\
\end{array}$ & $\begin{array}{c}-0.449 \\
(0.244) \\
-0.142 \\
\end{array}$ & $\begin{array}{c}-0.384 \\
(0.130) \\
-0.152 \\
\end{array}$ & $\begin{array}{c}-0.460 \\
(0.164) \\
-0.178 \\
\end{array}$ & $\begin{array}{c}-0.431 \\
(0.244) \\
-0.148 \\
\end{array}$ & $\begin{array}{c}-0.034 \\
(0.092) \\
-0.003 \\
\end{array}$ & $\begin{array}{c}-0.124 \\
(0.100) \\
-0.007 \\
\end{array}$ & $\begin{array}{c}-0.098 \\
(0.109) \\
-0.004 \\
\end{array}$ & $\begin{array}{c}-0.069 \\
(0.093) \\
-0.005 \\
\end{array}$ & $\begin{array}{c}-0.150 \\
(0.102) \\
-0.008 \\
\end{array}$ & $\begin{array}{l}-0.110 \\
(0.110) \\
-0.004 \\
\end{array}$ \\
\hline & $\begin{array}{l}\text { sonal } \\
\text { vices }\end{array}$ & \begin{tabular}{|c|}
-0.179 \\
$(0.166)$ \\
-0.069
\end{tabular} & $\begin{array}{c}-0.233 \\
(0.196) \\
-0.084\end{array}$ & $\begin{array}{l}-0.009 \\
(0.292) \\
-0.003\end{array}$ & $\begin{array}{c}-0.164 \\
(0.170) \\
-0.065\end{array}$ & $\begin{array}{c}-0.166 \\
(0.206) \\
-0.065\end{array}$ & $\begin{array}{l}-0.009 \\
(0.291) \\
-0.003\end{array}$ & $\begin{array}{c}0.061 \\
(0.144) \\
0.005\end{array}$ & $\begin{array}{c}0.056 \\
(0.149) \\
0.003\end{array}$ & $\begin{array}{c}0.117 \\
(0.155) \\
0.006\end{array}$ & $\begin{array}{c}0.079 \\
(0.146) \\
0.006\end{array}$ & $\begin{array}{c}0.087 \\
(0.153) \\
0.005\end{array}$ & $\begin{array}{c}0.143 \\
(0.158) \\
0.007\end{array}$ \\
\hline & ill- & $\begin{array}{c}0.262 \\
(0.094) \\
0.102 \\
\end{array}$ & $\begin{array}{c}0.237 \\
(0.111) \\
0.088 \\
\end{array}$ & $\begin{array}{c}0.294 \\
(0.171) \\
0.093 \\
\end{array}$ & $\begin{array}{c}0.260 \\
(0.097) \\
0.103 \\
\end{array}$ & $\begin{array}{c}0.236 \\
(0.116) \\
0.093 \\
\end{array}$ & $\begin{array}{c}0.310 \\
(0.168) \\
0.112 \\
\end{array}$ & $\begin{array}{c}-0.333 \\
(0.073) \\
-0.032 \\
\end{array}$ & $\begin{array}{c}-0.317 \\
(0.079) \\
-0.022 \\
\end{array}$ & $\begin{array}{c}-0.195 \\
(0.085) \\
-0.009 \\
\end{array}$ & $\begin{array}{c}-0.359 \\
(0.074) \\
-0.032 \\
\end{array}$ & $\begin{array}{c}-0.346 \\
(0.079) \\
-0.023 \\
\end{array}$ & $\begin{array}{c}-0.221 \\
(0.086) \\
-0.010 \\
\end{array}$ \\
\hline \multicolumn{2}{|l|}{$\rho$} & \begin{tabular}{|c|}
-0.300 \\
$(0.132)$ \\
\end{tabular} & \begin{tabular}{c|}
-0.381 \\
$(0.153)$ \\
\end{tabular} & $\begin{array}{c}0.131 \\
(0.280) \\
\end{array}$ & 0 & 0 & 0 & $\begin{array}{c}0.373 \\
(0.149) \\
\end{array}$ & $\begin{array}{c}0.500 \\
(0.197) \\
\end{array}$ & \begin{tabular}{|c|}
0.617 \\
$(0.309)$ \\
\end{tabular} & 0 & 0 & 0 \\
\hline \multicolumn{2}{|c|}{\begin{tabular}{|l} 
Log likelihood \\
\end{tabular}} & -3256.5 & -2328.4 & -1456.5 & -704.79 & -443.8 & -213.1 & -3685.4 & -2845.1 & -2030.7 & -1134.7 & -961.0 & -790.9 \\
\hline \multicolumn{2}{|c|}{ Observed prob. } & 0.541 & 0.472 & 0.356 & 0.541 & 0.472 & 0.356 & 0.044 & 0.035 & 0.026 & 0.051 & 0.038 & 0.027 \\
\hline \multicolumn{2}{|c|}{ Predicted prob. } & 0.536 & 0.469 & 0.347 & 0.543 & 0.468 & 0.333 & 0.045 & 0.035 & 0.026 & 0.032 & 0.022 & 0.027 \\
\hline \multicolumn{2}{|l|}{$N$} & 7617 & 7617 & 7615 & 1114 & 688 & 368 & 7617 & 7617 & 7615 & 6503 & 6929 & 7247 \\
\hline \multicolumn{14}{|c|}{$\begin{array}{l}\text { Note: For each variable, the first line displays the estimated coefficient, the second line the standard error in brackets, and the third line } \\
\text { the marginal effects (in italics). The marginal effects are calculated as the change in the probability associated with a discrete change of } \\
\text { the dummy variable from } 0 \text { to } 1 \text { evaluated at the mean of other variables. The marginal effect of education is calculated as the change in } \\
\text { the probability associated with a change from } 9 \text { to } 12 \text { years of formal schooling. The marginal effect of experience is calculated as the } \\
\text { change in the probability associated with a change of the age from } 35 \text { to } 40 \text { years. Cells shaded gray indicate statistical significance of } \\
\text { the coefficients at least at the } 90 \text { percent level. The variable bank and insurance was dropped in one equation since no individual was } \\
\text { low-paid in these sectors two consecutive years. }\end{array}$} \\
\hline
\end{tabular}

From Table 6 we can see that many variables that were statistically significant in the previous selection equation have lost their significance now. Apparently they contain some explanatory power for the selection into a particular state, but seem not to affect transitions between wage classes.

Variables we attach a great importance to are educational qualifications and work experience. They seem not only pertinent from a human capital theoretical point of view, but as well represent the main variables that can be influenced by certain policy measures, be it through vocational training or that acquired work experience is better valued. With the exception of the CHF 3,000 threshold additional years of education seem to prevent a stay in the low-wage segment. The same holds for the probability of dropping into the low-wage segment. However, the effect is rather weak, and for the lowest threshold it is not even significant. Rather surprisingly, the acquired years of work experience measured by age are never significant in reducing the probability of remaining low-paid and as well in preventing a drop into the low-wage segment 
(with the exception of the CHF 3,000 threshold). This contrasts with the human capital approach to wage formation and only makes sense when perceiving these low-paid jobs as "bad" jobs with no skill content. ${ }^{14}$

The results for education and experience are visualized in Figures 3 and 4 . While the probability plot against education conforms to our expectation this is not necessarily the case for experience. Many years of experience are apparently hardly reducing the probability of remaining low-paid, but as well a drop is hardly reduced with higher experience. This certainly contradicts the typical belief according to which wages are continuously increasing with seniority. The probability of remaining low-paid and the probability of falling into the low-wage segment remain virtually the same regardless of whether a person possesses one year of work experience or whether she possesses 20 years of work experience. It is worth mentioning that the plots look similar when considering the other thresholds.

Working in sectors such as the banking and the insurance branch or transportation and telecommunication significantly reduces the probability of remaining or falling into a low paid employment. Typically enough, there were not sufficient observations to assess the effect of staying below half the median threshold for persons working in the banking and insurance business. For this reason this dummy variable had to be dropped in these equations. ${ }^{15}$

Figure 3: Probability Plot $\operatorname{Pr}\left(y_{t}=1 \mid y_{t-1}=1\right)$ for the 2/3 Median Threshold against Education ${ }^{16}$

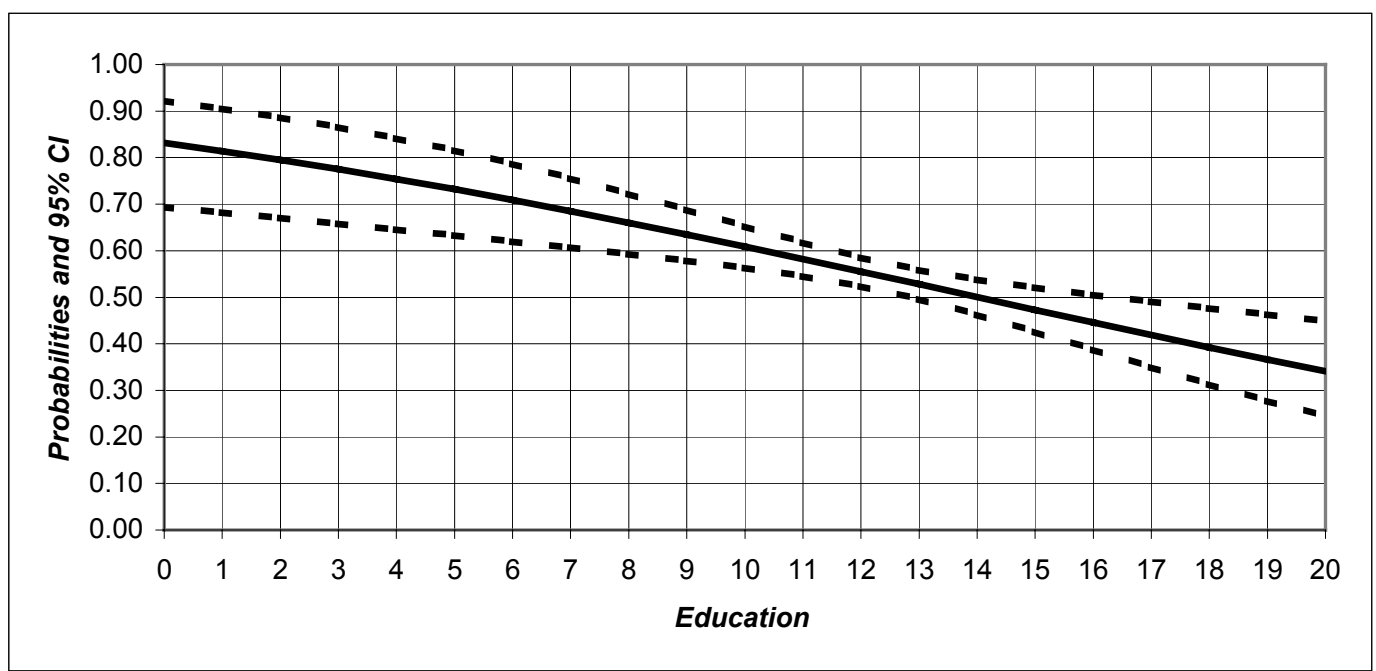

\footnotetext{
${ }^{14}$ Interestingly, similar results with regard to education and experience are obtained by CAPELLARI (1999) who investigates low-wage mobility in the Italian labor market.

${ }^{15}$ Some statistically insignificant results may also be attributable to the number of observations being quite sparse in some categories.

${ }^{16}$ The probability plots in Figure 3 and 4 were obtained with the simple probit model.
} 

measured by the Age

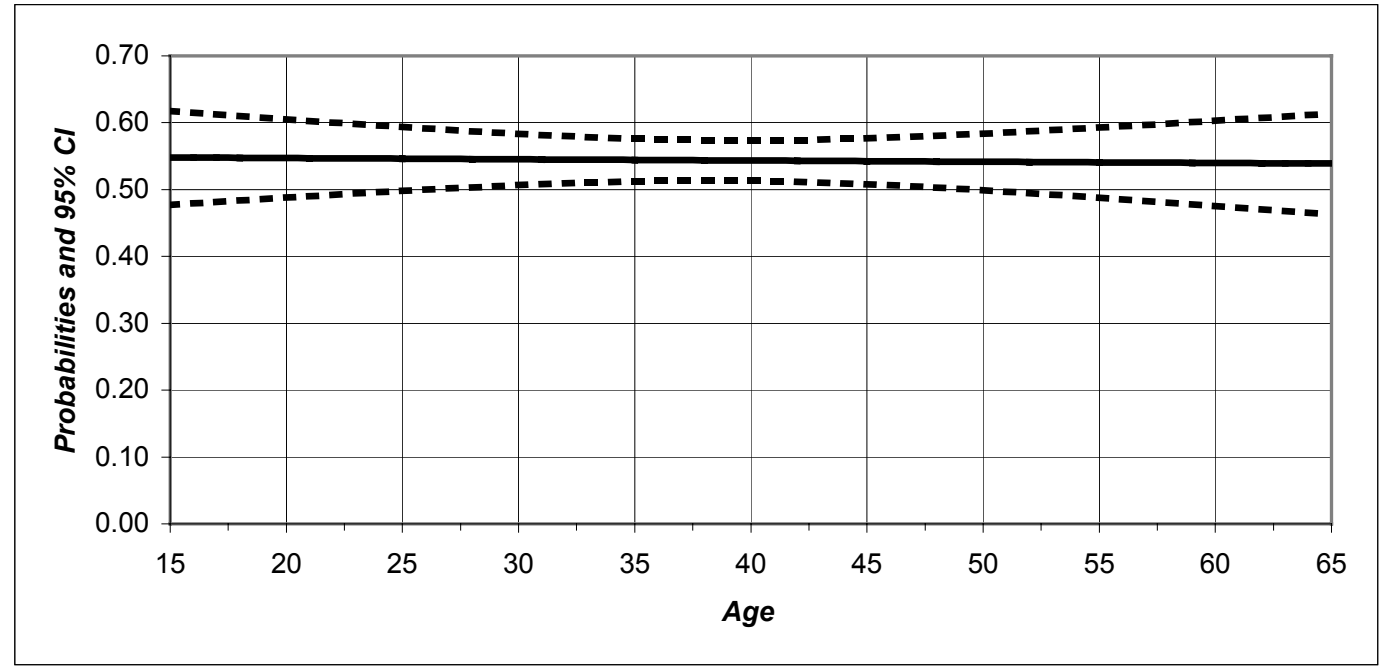

We find negative coefficients for most economic sectors with regard to the probability of remaining lowpaid over two consecutive periods on the one hand, but on the other we find some positive effects when considering the probability of dropping into the low-wage segment. This effect is particularly pronounced for the hotel and restaurant sector. ${ }^{17}$ This points to a pronounced job-mobility. It seems thus very likely that only those workers remain employed in the hotel and restaurant business who earn sufficiently high wages. Those workers, in turn, who earn very low wages apparently leave their job more frequently for a better paying job in another sector. ${ }^{18}$ This subsequently produces a negative marginal effect when assessing the probability of remaining low-paid. This explanation is actually endorsed by the rather high probability of dropping below any of the thresholds when coming from a higher-paid job (between 6 and 15 percent). The same as for the hotel and restaurant business seems true for the primary sector and the wholesale, retail an trade sector.

Again, we can see that working in a small firm increases the probability of remaining low-paid over two years, and the probability to drop below the low-pay threshold when initially high-paid is positive and statistically significant.

Turning now to the technical aspect of the estimation results shows that the initial state is often correlated with a subsequent transition ( $\rho$ is statistically different from zero in five out of six estimations), and that the sign of $\rho$ mostly agrees with a priori expectations. The negative correlation between the initial state and a subsequent transition in the first transition equation captures the relation between the probability of experi-

\footnotetext{
${ }^{17}$ A similar effect is observed for the full-time variable.
} 
encing a positive wage change and the probability of having a low initial wage: it is analogous to a negative coefficient in a standard regression of wage changes on their initial level. The positive correlation between being high-paid initially and low-paid subsequently, in turn, reflects the outcome complementary to a negative correlation of remaining high-paid over consecutive periods. The coefficient estimates between the simple probit model and the endogenous selection model for this reason differ when $\rho$ is significantly different from zero, which implies that we have to treat the initial state as endogenous. It is therefore not surprising to find that the instruments controlling for the initial state turn out to be jointly significant (the LRTest rejects the hypothesis of no significance at the 5 percent level). The comparison of the two models also reveals that the coefficient estimates are sensitive to the imposition of the restriction $\rho=0$. They are slightly inflated in the probit model compared to the endogenous selection model, i.e they tend to over- or underestimate the effect.

\section{State Dependence versus Heterogeneity}

We may ask now how much the explanatory variables (observed heterogeneity) account for the low-pay persistence. The state dependence effect is estimated as follows: Firstly, the predicted conditional probability of being low-paid in period $t$ provided being low paid in period $t-1$ as given by the equation (3) is calculated for each individual, for his specific set of covariates. These (hypothetical) probabilities are subsequently averaged over first those low-paid in $t-1$, and then those high paid in $t-1$. The difference between the two quantities is the contribution that is not due to state dependence. The latter effect is then calculated as the difference between the average probability of being low-paid in $t$ given being low-paid in $t$ - 1 over the sample who in fact were high-paid in $t-1$ and the raw aggregate probability of being low-paid in $t$ over the sample. Formally the overall measure of state dependence may be obtained from:

$$
\text { stdep }=\frac{\sum_{i \mid y_{i t-1}=1} \frac{\Phi_{2}\left(x_{i t-1}^{\prime} \hat{\beta}, z_{i t}^{\prime} \hat{\gamma} ; \hat{\rho}\right)}{\Phi\left(x_{i t-1}^{\prime} \hat{\beta}\right)}}{\sum_{i \mid y_{i t-1}=0} y_{i t-1}}-\frac{\sum_{i \mid y_{i t-1}=0} \frac{\Phi_{2}\left(x_{i t-1}^{\prime} \hat{\beta}, z_{i t}^{\prime} \hat{\gamma} ; \hat{\rho}\right)}{\Phi\left(x_{i t-1}^{\prime} \hat{\beta}\right)}}{\sum_{i \mid y_{i t-1}=1} y_{i t-1}} .
$$

This seems a natural way of computing the state dependence effect for it returns the part not explained by individual heterogeneity. However, it should also be noted that this method equates the state dependence effect with the residuals capturing everything the model omits, including unobserved heterogeneity. As a consequence, the less the model explains, the higher the state dependence effect tends to be. The decomposition results are reported in Table 7.

\footnotetext{
${ }^{18}$ An additional piece of evidence in favor of the hypothesis of a pronounced job-mobility is provided by the persis-
} 
Within our specification, heterogeneity obviously plays a minor role, which is to say that the reasons for remaining low-paid are mainly due to state dependence. The latter varies between 71 and almost 84 percent depending on which threshold is considered (lines 8 and 13 in Table 8). Comparing these results with those of STEWART and SWAFFIELD (1999) where state dependence accounts for 56 up to 76 percent of low-pay persistence, it needs to be emphasized that our results showing a higher state dependence effect may also be explained by the fact that their data set is considerably richer than ours. They were able to introduce 38 parental background variables containing attributes of the socioeconomic group of the mother and the father when the respondent was 14 years old. Moreover, they were able to control for whether the father was deceased or was not working. By this they clearly reduced the part of unobserved heterogeneity by a considerable amount.

Table 7: Heterogeneity and State Dependence Effect

\begin{tabular}{llll}
\hline & $2 / 3$ median & CHF 3,000 & $1 / 2$ median \\
\hline \hline Conditional probabilities: & &
\end{tabular}

Conditional probabilities:

Raw Transition Probabilities

$\begin{array}{lccc}\text { 1) } \operatorname{Pr}\left(y_{t}=1 \mid y_{t-1}=1\right) & 54.1 & 47.2 & 35.6 \\ \text { 2) } \operatorname{Pr}\left(y_{t}=1 \mid y_{t-1}=0\right) & 5.1 & 3.8 & 2.7 \\ \text { 3) Difference } & 49 & 43.4 & 32.9\end{array}$

\section{Probit Model}

4) $\operatorname{Pr}\left(y_{t}=1 \mid y_{t-1}=1\right)$ averaged over $y_{t-1}=1 \quad 54.1 \quad 35.6$

5) $\operatorname{Pr}\left(y_{t}=1 \mid y_{t-1}=1\right)$ averaged over $y_{t-1}=0 \quad 38.9 \quad 34.9 \quad 28.2$

6) Difference $\quad 15.2 \quad 12.3 \quad 7.4$

7) State Dependence Effect 3)-6) $\quad 33.8 \quad 31.1 \quad 25.5$

\begin{tabular}{llll}
$8) 7) / 3)$ & $69.0 \%$ & $71.7 \%$ & $77.5 \%$ \\
\hline
\end{tabular}

\section{Endogenous Selection Model}

10) $\operatorname{Pr}\left(y_{t}=1 \mid y_{t-1}=1\right)$ averaged over $y_{t-1}=0 \quad 37.1 \quad 33.6 \quad 29.4$

11) Difference $\quad 17.0 \quad 13.6 \quad 6.2$

12) State Dependence Effect 3)-11) $\quad 32.0 \quad 29.8 \quad 26.7$

\begin{tabular}{lrrr}
$13)(12) / 3)$ & $71.8 \%$ & $75.5 \%$ & $81.2 \%$ \\
\hline
\end{tabular}

To summarize, we find that an important share of workers low-paid at a particular point in time succeeds in escaping the low-pay segment tow years later. According to our estimates this share varies between 56 and 64 percent depending on the threshold considered. These numbers thus reflect a pronounced mobility out of low-paying jobs. According to the calculations in Table 7 we in turn also find a pronounced state dependence effect. Clearly, this latter effect pertains to the share of workers remaining low-paid, which is to say that for the 36 to 44 percent of workers that remain in the low-wage segment two years consecutively, state dependence dominates. The results in Table 7 also show that state dependence is larger the lower the low- 
pay threshold is. This indicates that those workers with personal characteristics that have a given effect on the low-pay probability are located higher up the wage distribution.

In order to make sense of this result it is important to recall that low-pay employment is highly concentrated in certain economically weak sectors recurring strongly either to female or foreign workers. In the case of foreigners it seems very likely that even if they possess higher formal education or more work experience on the average they still earn lower wages. Some stigmatization effect may be responsible for this, but as well discriminatory behavior. ${ }^{19}$ A similar reasoning applies to women. Wage regressions conducted for Switzerland typically show a discriminatory component of up to 25 percent when comparing wages of female and male workers and controlling for their different attributes (see for instance BONJOUR and GERFIN 1998). This wage differential reflects the part not explained by differences in the characteristics typically seen as influencing individual productivity and are thus subsumed in the state dependence effect.

\section{Summary and Conclusions}

The paper has investigated wage mobility in Switzerland, placing a particular emphasis on those workers at the lower tail of the wage distribution. The main findings from our analysis may be summarized as follows:

a) Looking first at the occupational mobility with the unrestricted data we find that between 27 and 40 percent of those workers initially low-paid succeed in escaping the low-wage segment over a two-year period. By contrast, only roughly 9 to 13 percent of the initially high-paid workers drop into a low-paid job. Between 20 and roughly 40 percent of those initially low-paid report no wage the next period compared to about 3 percent of those initially high-paid. Moreover, the probability of being unemployed or not being in the labor force anymore the next period is substantially higher for initially low-paid individuals than for initially high-paid individuals. This may be interpreted as a sign of larger involuntary (or forced) labor supply adjustments at the lower end of the wage distribution.

b) Analyzing aggregate transition probabilities by means of a standard transition matrix reveals that the stayer probabilities are higher at the extremes of the wages distribution. Mobility yet increases towards the middle range of the wage distribution. This pattern agrees with that found in most European countries.

c) Investigating the determinants of low-pay incidence shows that more years of education and of work experience significantly reduce the probability of being low-paid. We also find evidence of some wage discrimination against female and foreign workers. Furthermore, the low-pay probability is considerably larger for workers in the primary sector, in the catering business and to some extent in personal services

\footnotetext{
${ }^{19}$ It is also important to note that foreign workers according to the existing immigration law are attributed a working permit only if there are no Swiss workers willing to fill the vacancy. Swiss workers are thus benefiting from a privileged treatment which inevitably results in discrimination of foreign workers.
} 
than in manufacturing. The probability of being low-paid is also higher in small firms. These evidences by and large agree with results obtained by standard wage equations.

d) Investigating the determinants of remaining low-paid over two years and dropping into the low-wage segment shows that workers initially low-paid exhibit a higher probability of being low-paid the next period than workers initially high-paid. The probability of remaining low-paid is positively correlated with attributes such as working in a small firm, being an employee or working full-time. A full-time employment nevertheless reduces the probability of dropping into the low-wage segment. Working in a firm with less than 20 employees, in turn, significantly increases the probability of dropping into the low-wage segment. Interestingly, we find that working in the catering business and personal services reduces the probability of remaining low-paid. On the other hand, working in these sectors increases the probability of dropping from an initially high-paid position into a low-paid position. This is indicative of a pronounced job mobility between economic sectors. Furthermore, we find that the probability of low-pay persistence is significantly smaller for male workers than for female workers. A negative correlation of low-pay persistence is also found for construction workers, persons working in the banking and insurance sector, in the transportation and communication sector and in the business service sector. A higher educational attainment reduces both the probability of remaining low-paid and of dropping into the low-wage segment. However, a longer work experience has no effect on the probability of escaping the low-wage segment.

e) Overall we find a pronounced mobility out of the low-pay segment. However, when investigating how much the explanatory variables account for the observed low-pay persistence we find that heterogeneity seems weak. State dependence clearly dominates heterogeneity, even though we concede that a certain part of this state dependence may be due to unobserved heterogeneity.

Overall, the results show that being low-paid at a certain point in time does not necessarily mean that one is trapped in a bad job. However, for a large share of workers that remain low-paid over two years, the probability of further staying low-paid is quite pronounced. Neither acquiring a better education nor a longer work experience will improve their labor market prospects. These workers apparently are caught in bad jobs requiring hardly any skills at all. Improving their labor market chances by increasing the years of schooling, for example by means of intensifying vocational training will therefore be of a limited success in helping them to escape the low-pay segment. Other measures suited to improve the welfare of the low-paid need, for this reason, to be evaluated. Since they also seem to experience a higher unemployment probability and larger drop out rates from the labor force, measures such as job enrichment, job enlargement or job rotation may improve their employment stability, for these measures tend to promote their occupational flexibility and increase the value of labor market experience. At the same time one needs to consider that not only personal characteristics seem detrimental to an escape from the low-wage segment, but as well job characteristics, in particular affiliation to structurally weak economic sectors. 


\section{References}

ANDERSON, T.W. and GoOdMAN, L.A. (1957): Statistical Inference about Markov Chains, in: Annals of Mathematical Statistics 28: 89-110.

BANE, M. and Ellwood, D. (1986): Slipping into and out of Poverty: the Dynamics of Spells, in: Journal of Human Resources 21(1): 1-23.

BARTHOLOMEW, D.J. (1967): Stochastic Models for Social Processes. Wiley, New York.

BONJOUR, D. and GERFIN, M. (1995): Einkommensungleichheit zwischen Frauen und Männern. Eine ökonometrische Analyse der Schweizerischen Arbeitskräfteerhebung: Kommentar, in: Swiss Journal of Economics and Statistics 4/1: 701-710.

FEDERAL OFFICE OF STATISTICS (1996): Niedrige Einkommen, ungeschützte Arbeitsverhältnisse und Ausschluss vom Arbeitsmarkt. Entwicklung einiger Indikatoren der SAKE 1991-1995.

SAKE News 5.

CAPPELlaRI, L. (1999): Low-Wage Mobility in the Italian Labour Market. Warwick Economics Research Paper 531. University of Warwick.

DEUTSCH, J., FLÜCKIGER, Y., and J. SilBeR (1999): La population des "bas salaires" et des "working poor" en Suisse, in: R. Fluder, M. Nolde, T. Priester, A. Wagner (eds.): Armut verstehen - Armut bekämpfen. Bundesamt für Statistik, Neuchâtel.

DickENS, R. (2000): Caught in a Trap? Wage Mobility in Great Britain: 1975-1994, in: Economica 67: 477-497.

HECKMAN, J.J. (1981): The incidental parameters problem and the problem of initial conditions in estimating a discrete-time data stochastic process, in: C.F. Manski and D. McFadden (eds.): Structural Analysis of Discrete Data with Econometric Applications. MIT Press, Cambridge, Mass.

HeCKMAN, J.J. and BORJAS, G. (1980): Does Unemployment Cause Future Unemployment? Definitions, Questions and Answers from a Continuous Time Model for Heterogeneity and State Dependence, in: Economica, 47, 247-283.

KÜNG GUGLER, A. and S. BLANK (1999): Inégalité des salaires en Suisse: pas d'augmentation sensible durant les années 90, in: Swiss Journal of Economics and Statistics 136: 307-317

LIECHTI, A. and KNÖPFEL, C. (1998): Trotz Einkommen kein Auskommen - working poor in der Schweiz. Ein Positionspapier der Caritas Schweiz. Caritas Verlag, Luzern.

Maitre, B. and Nolan, B. (1999): Income Mobility in the European Community Household Panel Survey. European Panel Analysis Group (EPAG) Working paper 1999-04, Institute for Social and Economic Research, University of Essex.

MENG, C.-L. and SchmidT, P. (1985); On the Cost of Partial Observability in the Bivariate Probit Model, in: International Economic Review 26: 71 - 85.

OECD (1996, 1997, 1998): Employment Outlook. Paris.

SHELDON, G. (1991): Zur Dynamik der Armut in der Schweiz, Eine Untersuchung beruhend auf der Einkommensentwicklung männlicher Erwerbspersonen, WWZ Studien, Basel. 
SHORROCKS, A.F. (1976): Income Mobility and the Markov Assumption, in: The Economic Journal 86: 566-578.

SHORROCKS, A.F. (1978): Income Inequality and Income Mobility, in: Journal of Economic Theory 19: 376-393.

Stewart, M.B. and J.K., Swaffield (1999): Low Pay Dynamics and Transition Probabilities, in: Economica 66: 23-42. 


\section{Q Queen Mary \\ University of London}

This working paper has been produced by the Department of Economics at Queen Mary, University of London

Copyright @ 2001 Augustin de Coulon and Boris A. Zürcher All rights reserved.

\section{Department of Economics}

Queen Mary, University of London

Mile End Road

London E1 4NS

Tel: +44 (0)20 78825096 or Fax: +44 (0)20 89833580

Email: j.conner@qmw.ac.uk

Website: www.econ.qmw.ac.uk/papers/wp.htm 